\title{
PENGARUH EDUKASI KESEHATAN DENGAN MEDIA AUDIOVISUAL TERHADAP PENGETAHUAN IBU TENTANG STUNTING PADA BALITA DI POSYANDU MELATI 1 KELURAHAN PISANGAN TIMUR, JAKARTA TIMUR
}

\author{
Tsania Ramadhanty1), Rokhaida2) \\ Program Studi Keperawatan, Fakultas Ilmu Kesehatan \\ Universitas Pembangunan Nasional Veteran Jakarta
}

\begin{abstract}
ABSTRAK
Stunting diartikan sebagai kegagalan pertumbuhan pada anak usia bawah lima tahun yang ditandai dengan panjang badan atau tinggi badan kurang menurut standar usia atau biasa disebut dengan anak berpostur tubuh pendek di usia pertumbuhan. Penelitian ini memiliki tujuan untuk mengetahui pengaruh edukasi kesehatan dengan media audiovisual terhadap pengetahuan ibu tentang stunting pada balita di posyandu melati 1 kelurahan pisangan timur, Jakarta timur. Desain penelitian yang digunakan adalah Quasy-eksperimental dengan one group pre post test, sampel yang digunakan pada penelitian ini adalah sebanyak 54 orang ibu yang memiliki anak usia balita (0-59 bulan) di wilayah posyandu melati 1 dengan menggunakan teknik purposive sampling. Berdasarkan analisis menggunakan uji Wilcoxon didapatkan nilai $\mathrm{P}=0,000$ yang memiliki arti terdapat perbedaan nilai ratarata pengetahuan ibu tentang stunting sebelum dan sesudah diberikan edukasi keshatan dengan media audiovisual. Terdapat pengaruh edukasi Kesehatan dengan media audiovisual terhadap pengetahuan ibu tentang stunting pada balita di posyandu melati 1 kelurahan pisangan timur Jakarta Timur.
\end{abstract}

Kata kunci: Edukasi Kesehatan, Audiovisual, Stunting, Pengetahuan Ibu

\begin{abstract}
Stunting is defined as growth failure in children under the age of five years which is characterized by body length or height that is less according to age standards or commonly referred to as children with short stature at the age of growth. This study aims to determine the effect of health education with audiovisual media on mother's knowledge about stunting in toddlers at Posyandu Melati 1, Pisangan Timur, Jakarta Timur. The research design used was Quasy-experimental with one group pre post test. the Pasrticipant in this study included 54 mothers who have children aged under five (0-59 months) in the Posyandu Melati 1 area using purposive sampling technique. Based on the analysis using the Wilcoxon test, $\mathrm{P}$ value $=0.000$ was obtained, which means that there is a difference in the average value of maternal knowledge about stunting before and after being given health education with audiovisual media. There is an effect of health education with audiovisual media on mother's knowledge about stunting in toddlers at Posyandu Melati 1, Pisangan Timur, Jakarta Timur.
\end{abstract}

Keywords: Health Education; Audiovisual; Stunting; Mother's Knowledge

Alamat korespondensi: Fakultas Ilmu Kesehatan, Universitas Pembangunan Nasional Veteran Jakarta, JalanLimo Raya Kelurahan Limo Kecamatan Limo Kota Depok Kode Pos 16515

Email: tsaniaramadhanty@upnvj.ac.id dan rokhaida@upnvj.ac.id 


\section{PENDAHULUAN}

Stunting biasa disebut dengan anak berpostur tubuh pendek di usia pertumbuhan (TNP2K, 2019). Stunting dikategorikan menjadi 4 klasifikasi berdasarkan nilai $Z$ score yang telah ditentukan yaitu ketegori tinggi dengan nilai sebesar $>3$ SD, normal sebesar -2 SD sampai dengan 3 SD, stunted sebesar -3 SD sampai dengan -2 SD dan severely stunted sebesar <-3 SD (Menteri Kesehatan Republik Indonesia, 2020a). Angka kejadian stunting di Indonesia masih cukup tergolong tinggi, sehingga Pemerintah semakin terdorong dalam melakukan penanggulangan stunting untuk menekan angka kejadian stunting di Indonesia (TNP2K, 2019).

Angka kejadian stunting di dunia menurut World Health Organization (WHO) tahun 2020 melaporkan sebesar 21,3\% atau sebanyak 144 juta anak dibawah 5 tahun mengalami stunting pada tahun 2019. Prevalensi stunting di dunia mengalami penurunan sejak tahun 2015 yaitu sebesar 155 juta anak dibawah 5 tahun. Jumlah stunting merupakan permasalah terbesar setelah angka kejadian wasting sebanyak 47 juta anak dan obesitas sebanyak 38.3 juta anak di dunia. Angka kejadian stunting di dunia didominasi oleh Asia sebesar 54\% dan Afrika sebesar 40\%. Data tersebut menunjukkan stunting terjadi Sebagian besar di beberapa negara berkembang yang memiliki pendapatan menengah hingga rendah (UNICEF, WHO, \& WORLD BANK GROUP, 2020). Indonesia merupakan salah satu negara berkembang yang memiliki prevalensi stunting yang tinggi. Prevalensi stunting yang terjadi di Indonesia pada tahun 2019 sebesar 27,6\% dan prevalensi stunting di DKI Jakarta sebesar 19,9\% (SSGBI, 2019). Permasalahan stunting di DKI Jakarta masih terus mengalami peningkatan sebesar 2,2\% dengan angka kejadian stunting pada tahun 2018 sebear 17,7\% (RISKESDAS, 2018).

Tingginya angka kejadian stunting di indonesia memberikan dampak besar terhadap kualitas sumber daya manusia dikemudian hari. Kemampuan intelektual pada anak yang tidak mengalami stunting akan lebih tinggi dibandingkan dengan anak yang mengalami stunting, dan tingkat produktivitasnya $20 \%$ lebih rendah pada anak yang mengalami stunting ketika dewasa. Selain itu penyakit degeneratif yang tidak menular lebih mudah dialami pada anak yang mengalami stunting, hal tersebut mengakibatkan Indonesia mengalami kerugian sebesar Rp260-300 triliun per tahun (TNP2K, 2019). Dampak lain yang ditimbulkan oleh stunting yaitu tinggi badan dan perkembangan kognitif tidak akan maksimal serta menjadi penyebab berkurangnya kualitas sumber daya manusia pada masa dewasa (UNICEF et al., 2020).

Dampak stunting tersebut dipengaruhi oleh berbagai faktor penyebab antara lain tidak adekuatnya nutrisi pada masa bayi, infeksi pada balita, faktor ekonomi, dan tidak terpenuhinya gizi yang adekuat pada masa kehamilan (Kemenkes RI, 2018). Kekurangan gizi kronik pada balita dan ibu hamil tidak selalu menjadi penyebab utama terjadinya stunting. Faktor penyebab stunting disebabkan oleh berbagai faktor, salah satunya adalah Pengasuhan orang tua tidak maksimal. Hal tersebut dipengaruhi oleh kurangnya pengetahuan ibu tentang stunting dan pengetahuan gizi yang tidak tepat sebelum hamil, saat hamil dan setelah melahirkan (TNP2K, 2017).

Menurut penelitian yang dilakukan oleh Olsa dkk didapatkan hasil pengetahuan ibu tentang stunting memiliki hubungan yang bermakna dengan kejadian stunting pada anak (Olsa, Sulastri, \& Anas, 2018). Pendapat lainnya juga didapatkan dengan penelitian yang dilakukan oleh Margawati dan Astuti yaitu menyimpulkan bahwa pengetahuan yang salah tentang stunting dimiliki pada ibu yang memiliki anak stunting. Ibu yang memiliki anak stunting berpendapat bahwa stunting bukan masalah yang serius untuk segera ditindak lanjuti (Margawati \& Astuti, 2018). Penelitian yang dilakukan oleh Suryagustina didapatkan pengetahuan ibu tentang pencegahan stunting dapat ditingkatkan dengan dilakukannya edukasi Kesehatan kepada ibu yang memiliki anak usia dini (Suryagustina \& Araya, 2018).

Edukasi Kesehatan atau Pendidikan Kesehatan selalu dilaksanakan menggunakan media atau alat. Media berasal dari Bahasa latin yaitu "medius" yang memiliki arti "perantara" atau "pengantar" yang memiliki fungsi untuk membantu komunikasi antara komunikator dengan komunikan. Perkembangan era globalisasi memberikan peranan besar terhadap media edukasi yang 
semakin kreatif dan inovatif. Perkembangan tersebut memberikan kemudahan komunikator dalam menyajikan informasi atau edukasi. Begitu juga sebaliknya siapapun dapat mengakses informasi atau edukasi dimana pun dan kapan pun secara online tanpa harus bertatap muka (I Nyoman Gejir dkk, 2017). Sejak awal tahun 2020 beberapa negara di dunia termasuk Indonesia mengalami puncak penyebaran virus covid-19 yang mengharuskan seluruh masyarakat untuk melakukan pembatasan kegiatan dengan skala besar, sehingga pelayanan dan Pendidikan Kesehatan tidak dapat lagi dilakukan secara offline (Lau et al., 2020). Berdasarkan penelitian yang dilakukan oleh Nurhasanah menyimpulkan Pendidikan atau edukasi Kesehatan tetap bisa dilakukan secara online menggunakan berbagai media atau alat sebagai pendukung dan memudahkan proses penyampaian informasi (Norhasanah \& Yuliana Salman, 2021). Maka peneliti tertarik melakukan penelitian tentang pengaruh edukasi dengan media audio visual terhadap pengetahuan ibu tentang stunting pada balita di posyandu melati 1 kelurahan pisangan timur, Jakarta Timur. Penelitian ini memiliki manfaat untuk memberikan informasi atau pengetahuan tentang stunting kepada ibu dengan balita untuk mencegah terjadinya stunting di posyandu Melati 1 Kelurahan Pisangan Timur.

\section{METODE PENELITIAN}

Jenis penelilitian yang digunakan oleh peneliti yaitu Quasy-eksperimental dengan menggunakan one group pre test-post test. Sampel yang digunakan pada penelitian ini adalah sebanyak 54 orang ibu yang memiliki anak usia balita (0-59 bulan) di wilayah posyandu melati 1 dengan menggunakan teknik purposive sampling yang memiliki kriteria inklusi antara lain: Ibu yang memiliki balita usia 0-59 bulan dan bertempat tinggal di wilayah kerja posyandu melati 1 RW 04 kelurahan pisangan timur, Ibu bersedia menjadi responden, Ibu memiliki handphone yang dapat mengakses internet, dan ibu dapat membaca.

Pada penelitian ini, peneliti menggunakan dua instrumen untuk melakukan penelitian, instrumen pertama yaitu berupa kuisioner dalam bentuk google form yang terdiri dari karakteristik ibu, karakteristik anak, serta pertanyaan seputar pengetahuan ibu tentang stunting dan diberikan sebelum diberikan intervensi dan setelah intervensi. Kuisioner terdiri dari 24 pernyataan yang bersifat pernyataan positif dan negatif. Kuisioner telah dinyatakan valid dan reliabel setelah dilakukan uji dengan mendapatkan hasil nilai rtabel 0,361 dan Cronbach alpha sebesar 0,816. Instrumen kedua yaitu berupa video animasi edukasi Kesehatan yang telah dilakukan uji validitas dengan berkonsultasi kepada Expertise yaitu dosen keperawatan spesialis anak. Video edukasi diberikan kepada responden melalui link Youtube yang dibagikan melalui grup Whatsapp edukasi stunting pada balita.

\section{HASIL DAN PEMBAHASAN}

Hasil analisa data univariat dapat dilihat pada tabel 1 dan tabel 2 yang berisikan tentang data demografi responden yaitu karakteristik ibu (usia ibu, tingkat Pendidikan, status pekerjaan), serta karakteristik anak (usia anak, jenis kelamin, status gizi anak terhadap stunting). sedangkan analisa bivariat yang berisikan pengetahuan ibu sebelum dan sesudah dilakukan intervensi Pendidikan Kesehatan dapat dilihat pada tabel 3. Hasil dari pengolahan data akan disajikan dalam bentuk data frekuensi dan distribusi. 
Table 1 Hasil Distribusi Rata-Rata Usia Ibu dan anak di Posyandu Melati 1 (n=54)

\begin{tabular}{lcccc}
\hline Karakteristik & Mean & SD & Minimal & Maksimal \\
\hline Usia ibu (tahun) & 30.44 & 4,697 & 20 & 42 \\
\hline Usia anak (bulan) & 26,61 & 12,558 & 2 & 48 \\
\hline
\end{tabular}

Hasil analisis usia yang telah dilakukan oleh peneliti berdasarkan tabel diatas didapatkan rata-rata usia ibu yang memiliki anak usia balita adalah 30,44, dengan usia terendah adalah 20 tahun serta usia tertinggi adalah 42 tahun. dimana pada usia ini keperdulian orang tua terhadap pertumbuhan dan perkembangan anak sangat tinggi sehingga penyerapan informasi seputar anak akan lebih mudah diserap dan dimengerti oleh orang tua (Rahmawati, 2019). sedangkan hasil analisis data kerakteristik usia anak balita didapatkan bahwa rata-rata usia anak balita yaitu 26,61 serta usia terendah balita yaitu 2 bulan dan usia tertinggi yaitu 48 bulan.

Table 2 Hasil Distribusi Frekuensi Karakteristik Ibu Menurut Tingkat Pendidikan, Status Pekejaan Serta Karakteristik Balita Menurut Jenis Kelamin Dan Status Gizi Di Posyandu Melati 1 (N=54)

\begin{tabular}{llcc}
\hline Karakteristik & Kategori & Frekuensi & Presentase (\%) \\
\hline Tingkat Pendidikan & Pendidikan rendah & 24 & 44,4 \\
& Pendidikan menengah & 25 & 46,3 \\
& Penddikan tinggi & 5 & 9,3 \\
\hline Status pekerjaan & Bekerja & 12 & 22,2 \\
& Tidak bekerja & 42 & 77,8 \\
\hline Jenis kelamin balita & Laki-laki & 26 & 48,1 \\
& Perempuan & 28 & 51,9 \\
\hline Status gizi (TB/U) & Stunting & 15 & 27,8 \\
& Normal & 39 & 72,2 \\
\hline
\end{tabular}

Berdasarkan hasil analisis data pada tabel diatas didapatkan kerakteristik responden pada tingkat Pendidikan ibu dari total 54 orang responden didapatkan kesimpulan pendidikan ibu yang memiliki pendidikan rendah dan menengah memiliki jumlah yang hampir sama yaitu sebesar 44,4\% dan $46,3 \%$. Selain itu data kerakteristik responden pada tingkat Pekerjaan ibu didapatkan bahwa Sebagian besar ibu tidak bekerja yaitu dengan total sebanyak 42 orang $(77,8 \%)$. Selajutnya pada data kerakteristik responden berdasarkan jenis kelamin anak didapatkan bahwa mayoritas balita berjenis kelamin perempuan sebanyak 28 orang anak (51,9\%). Serta yang terakhir data karakteristik responden pada tingkat status gizi balita didapatkan berdasarkan hasil analisis data kerakteristik responden pada satus gizi anak melalui perhitungan nilai Z-Score yang dihitung berdasarkan jenis kelamin, usia anak serta tinggi badan/Panjang badan anak maka didapatkan bahwa jumlah anak yang mengalami stunting sebanyak 15 orang $(27,8 \%)$. Menurut WHO suatu wilayah dikatakan memiliki tingkat kejadian stunting yang tinggi bila prevalensi anak yang mengalami stunting melebihi melebihi 20\% (WHO, 2012). 
Table 3 Distribusi Rata Rata Pengetahuan Ibu Tentang Stunting Sebelum Dan Sesudah Diberikan Edukasi Kesehatan Di Posyandu Melati 1 (N=54)

\begin{tabular}{|c|c|c|c|c|c|}
\hline Karakteristik & $\mathbf{N}$ & Mean & $\begin{array}{c}\text { Mean } \\
\text { Differences }\end{array}$ & SD & P-Value \\
\hline Pretest & 54 & 12.26 & \multirow{2}{*}{6,04} & 4.683 & \multirow{2}{*}{0,000} \\
\hline posttest & 54 & 18,30 & & 2.567 & \\
\hline
\end{tabular}

Berdasarkan hasil data pada tabel diatas menunjukan hasil analisis pengaruh edukasi Kesehatan dengan media audiovisual terhadap pengetahuan ibu tentang stunting. Tabel diatas menunjukkan nilai pengetahuan ibu tentang stunting dengan media audiovisual sebelum dan sesudah diberikan edukasi Kesehatan dengan nilai rata-rata sebesar 12,26 yang menunjukkan pengetahuan ibu cukup dan pengetahuan ibu sesudah diberikan edukasi Kesehatan dengan nilai rata-rata sebesar 18,30 yang menunjukkan pengetahuan ibu menjadi baik, sehingga didapatkan peningkatan rata-rata pengetahuan ibu tentang stunting yaitu sebesar 6,04.

Pengetahuan merupakan suatu proses setelah penginderaan terhadap objek tertentu yang menghasilkan rasa tahu pada seseorang. Penginderaan dapat berasal dari beberapa sumber yaitu penglihatan, pendengaran, penciuman, dan indera perasa atau peraba. Sebagian besar pengetahuan seseorang didapatkan sesuai penglihatan dan pendengaran (Sukidjo Notoatmodjo, 2012). Menurut penelitian yang dilakukan oleh Margawati dkk tahun 2018 terdapat hubungan yang signifikan antara pengetahuan yang dimiliki oleh ibu dengan kejadian stunting pada anak usia balita, dimana pengetahuan tentang stunting yang tidak tepat dimiliki oleh Sebagian besar ibu yang memiliki anak dengan gangguan stunting, stunting tidak dianggap penting oleh ibu karena tidak terlalu memberikan dampak yang mengkhawatirkan dan menganggap stunting bukan suatu hal yang serius dan harus ditindak lanjuti (Margawati \& Astuti, 2018).

Pengetahuan stunting pada ibu dapat dipengaruhi oleh beberapa faktor. Menurut penelitian yang dilakukan oleh Rahmawati tahun 2019 disimpulkan faktor yang mempengaruhi pengetahuan pada ibu antara lain yaitu tingkat Pendidikan, usia dan informasi yang diterima. Faktor utama yang paling berpengaruh terhadap pengetahuan ibu adalah informasi, dimana pada penelitian ini didapatkan Sebagian besar ibu yang memiliki pengetahuan yang baik sering menerima berbagai informasi tentang stunting dari berbagai jenis media, sehingga pemberian informasi melalui edukasi Kesehatan sangat berpengaruh terhadap peningkatan pengetahuan ibu tentang stunting (Rahmawati, 2019).

Pada tabel diatas juga didapatkan berdasarkan Hasil uji Wilcoxon nilai P-Value 0,000 $<0,05$ sehingga Ha diterima. Hasil analisis tersebut memiliki arti terdapat pengaruh edukasi Kesehatan dengan media audiovisual terhadap pengetahuan ibu tentang stunting pada balita di posyandu melati 1 kelurahan pisangan timur, Jakarta timur. Hasil penelitian tersebut berbanding lurus dengan penelitian yang dilakukan oleh Susilowati didapatkan bahwa terjadi peningkatan pengetahuan stunting setelah diberikan edukasi Kesehatan dengan media audiovisual dimasa pandemi covid-19. Media audiovisual dapat meningkatkan pengetahuan ibu dengan menarik perhatian responden dan menambah pemahaman pada ibu yang memiliki anak usia balita (Susilowati, Trisetiyaningsih, \& Nursanti, 2021). Penelitian lainnya yang dilakukan oleh Wahyurin dkk (2019) didapatkan bahwa terdapat perbedaan pengetahuan setelah diberikan edukasi Kesehatan dengan metode brainstorming dan audiovisual dengan nilai $\mathrm{P}=0,009(\mathrm{P}<0,05)$. Pada penelitian ini terdapat peningkatan nilai ratarata pengetahuan ibu tentang stunting sebesar 0,94 sehingga dapat disimpulkan edukasi kesehatan menggunakan metode brainstorming dan media audiovisual memberikan pengaruh terhadap pengetahuan ibu tentang stunting (Wahyurin et al., 2019) 
Media audio visual memiliki beberapa kelebihan dari pada media lainnya. yaitu informasi dapat diberikan kepada masyarakat luas, populasi yang banyak, serta tidak memerlukan peralatan yang rumit dalam penyampaian informasi. Kelebihan media audio visual lainnya informasi yang hasilkan adalah berupa suara dan gambar yang apat diterima oleh indera pendengaran dan penglihatan sekaligus yang akan membuat responden lebih mudah mencerna atau memahami isi informasi. Media audio visual juga memiliki beberapa fungsi dalam pemberian Pendidikan kesehatan yaitu fungsi edukasi, fungsi sosial, serta fungsi ekonomis (Asmuji \& Faridah, 2018b). Pendapat tersebut juga didukung oleh Penelitian yang dilakukan oleh Dianna didapatkan bahwa terdapat perbedaan pengetahuan setelah diberikan edukasi Kesehatan dengan media audiovisual dan leaflet dengan nilai $\mathrm{P}=0,001(\mathrm{P}<0,05)$. Pada penelitian ini juga didapatkan perbedaan peningkatan nilai pengetahuan stunting pada masing-masing media edukasi yang digunakan yaitu media audiovisual dan leaflet. Peningkatan nilai pengetahuan ibu tentang stunting menggunakan media audiovisual meningkat sebesar 4 poin, sedangkan leaflet sebesar 3 poin. Hal ini menunjukkan media audiovisual lebih efektif dalam meningkatkan pengetahuan stunting pada ibu yag memiliki anak usia balita (Dianna et al., 2020).

Pada penelitian ini, peneliti memanfaatkan media audiovisual untuk melakukan edukasi Kesehatan dimasa pademi Covid-19. Pemberian edukasi Kesehatan yang dilakukan oleh tenaga Kesehatan mengalami perubahan cukup drastis di masa pandemi Covid-19. Pendidikan Kesehatan tidak dapat diberikan secara langsung dengan pengumpulkan responden pada suatu tempat dikarenakan saat ini masih diberlakukannya pembatasan sosial berskala besar, sehingga tenaga Kesehatan memanfaatkan kemajuan teknologi dengan melakukan Konsultasi, Informasi, dan edukasi secara online berbasis internet untuk menghubungkan antara komunikator dengan komunikan dan menghindari resiko penularan virus Covid-19 (Pradana et al., 2020). Berdasarkan penelitian yang dilakukan oleh Widianti, Pendidikan Kesehatan tetap dapat dilakukan dengan memberikan video edukasi secara online tentang pengetahuan Kesehatan reproduksi wanita dan didapatkan hasil terdapat peningkatan pengetahuan setelah dilakukan penyuluhan Kesehatan secara online (Widianti et al., 2021).

Sehingga peneliti berpendapat bahwa edukasi Kesehatan yang dilakukan dengan media audiovisal dimasa pandemi Covid-19 serta memanfaatkan kemajuan teknologi Smartphone dan internet dapat dijadikan program untuk meningkatkan pengetahuan dan informasi bagi seluruh masyarakat kapanpun dan dimanapun.

\section{SIMPULAN}

Karakteristik ibu yang memiliki anak usia balita di Posyandu Melati 1 Kelurahan Pisangan Timur sebanyak 54 orang didapatkan rentang usia ibu adalah 20 - 42 tahun. Lalu tingkat Pendidikan ibu yang berpendidikan rendah hampir sama dengan ibu yang berpendidikan menengah, Serta status pekerjaan ibu yaitu mayoritas tidak bekerja sebanyak 42 orang 77,8\%. Sedangkan Karakteristik anak usia balita didapatkan rentang usia anak balita yaitu 2 - 48 bulan. Lalu Sebagian besar jenis kelamin anak adalah wanita sebesar 51,9\%. Serta jumlah kejadian stunting pada anak usia balita di wilayah tersebut adalah sebesar 27,8\%. Perbedaan rata-rata skor pengetahuan ibu sebelum dan sesudah dilakukan edukasi Kesehatan tentang stunting adalah sebesar 6,04 yang berarti terdapat perubahan tingkat pengetahuan ibu tentang stunting dari tingkat pengetahuan cukup menjadi baik. serta didapatkan nilai $\mathrm{p}$ value $=0,000(\mathrm{p}<0,05)$ yang berarti terdapat pengaruh edukasi Kesehatan dengan media audiovisual terhadap pengetahuan ibu tentang stunting pada balita di posyandu melati 1 kelurahan Pisangan Timur, Jakarta timur. 


\section{SARAN}

Bagi ibu yang memiliki anak usia 0-59 bulan disarankan agar mencari lebih banyak informasi tentang stunting dan pemenuhan gizi anak. Bagi kepala dinas Kesehatan diharapkan dapat membuat program kesehatan untuk mencegah terjadinya stunting seperti pemberian informasi terkait stunting secara meluas serta program pencegahan stunting lainnya yang dapat diterapkan untuk menurunkan angka kejadian stunting dimasa yang akan datang terutama dimasa pandemi Covid-19. Bagi pelayanan Kesehatan diharapkan dapat mencari alternatif segera untuk medukung serta memotivasi ibu untuk tetap melakukan pemberian gizi yang baik, pemeriksaan balita rutin dan imunisasi lengkap dimasa pandemi Covid-19 sebagai upaya menurunkan prevalesi stunting. Bagi peneliti selanjutnya yang akan melakukan penelitian edukasi Kesehatan dengan media audiovisual diharapkan untuk melakukan penelitian menggunakan kelompok pembanding, ditetapkan frekuensi berapa kali responden harus menonton video edukasi dalam waktu sehari atau ditetapkan frekuensi pemberian intervensi, lalu lebih memperhatikan kesamaan dari karakteristik tiap responden, serta menggunakan skala multiple choice pada jawaban kuisioner pengetahuan dengan tujuan untuk mengecoh responden sehingga responden dapat menjawab dengan lebih teliti.

\section{DAFTAR PUSTAKA}

Dianna, Septianingsih, N., \& Pangestu, J. F. 2020. Perbedaan Pengetahuan Ibu Balita Sebelum Dan Sesudah Sesudah Diberikan Penyuluhan Tentang Stunting Melalui Media Video Dan Leaflet Di Wilayah Kerja Puskesmas Saigon Kecamatan Pontianak Timur. Jurnal Kebidanan Khatulistiwa, 6(1), 7. https://doi.org/10.30602/jkk.v6i1.493

Rahmawati, A. 2019. Faktor yang Berhubungan dengan Pengetahuan Orang Tua tentang Stunting pada Balita. Jurnal Ners Dan Kebidanan (Journal of Ners and Midwifery), 6(3), 389-395. https://doi.org/10.26699/jnk.v6i3.art.p389-395

Susilowati, L., Trisetiyaningsih, Y., \& Nursanti, I. 2021. Pencegahan Stunting pada Balita Selama Masa Pandemi Covid-19 Melalui Edukasi Audiovisual. Community Empowerment, 6(4), 563-567. https://doi.org/10.31603/ce.4500

Wahyurin, I. S., Aqmarina, A. N., Rahmah, H. A., Hasanah, A. U., \& Silaen, C. N. B. 2019. Pengaruh edukasi stunting menggunakan metode brainstorming dan audiovisual terhadap pengetahuan ibu dengan anak stunting. Ilmu Gizi Indonesia, 2(2), 141. https:/ / doi.org/10.35842/ilgi.v2i2.111

WHO. 2012. Nutrition Landscape Information System: Country Profile Indicator Interpretation Guide.

Widyaningsih, N. N., Kusnandar, K., \& Anantanyu, S. 2018. Keragaman pangan, pola asuh makan dan kejadian stunting pada balita usia 24-59 bulan. Jurnal Gizi Indonesia (The Indonesian Journal of Nutrition), 7(1), 22-29. https://doi.org/10.14710/jgi.7.1.22-29. 